\title{
THE LANGUAGE LABORATORY AS MEDIUM AND MODEL IN A TALK-WRITE COMPOSITION COURSE
}

\author{
by James E. Davis
}

Hundreds of times over the last twenty years or so as I have conferenced with students about their writing and discovered ill-formed constructions or confusing, sometimes meaningless, passages, they have said to me something like, "Well, this is what I meant to say..." and then proceeded to spill forth whole series of thoughtful, wellformed sentences. Over and over I could say to them "Write that down!" Then, sometimes with slight editing, they could get on paper what they desired to communicate. When I would then sit with them and just ask them to write directly on the paper, I would find, more often than not, that they could not communicate nearly so well.

There must be something lacking somewhere in the think-write model that teachers of composition so frequently use. I knew this for years before I finally saw a new theory worked out rather thoroughly in the work of Robert Zoellner in an article in College English entitled "Talk.Write: a Behavioral Pedagogy of Composition."1 Zoellner maintained that speech utterances could be used to improve student's compositions. He called it shifting "from the scribal modality to the vocal modality." 2 A think $\rightarrow$ talk $\rightarrow$ write model emerges along with a proposal for using operant conditioning to elicit oral responses that could then be written down. Not too different from what I had been trying to do in my conferences with students, but still not quite specific enough or clear enough for me to formulate definite classroom teaching strategies from day to day.

Many students would have difficulty remembering, even immediately after the moment of utterance, what they had said orally! What would be needed would be some means of storing the student's speech communication until he was ready to edit and write it down, Tape recorders provided the obvious solution, but how to have tape recorders available for a whole class? The language lab was a possible solution. But how about those little enclosed spaces that would tend to isolate students from one another? As it evolved, this gave me an opportunity to incorporate another idea into a class design. I would

'Robert Zoellner, "Talk-Write: a Behavioral Pedagogy of Composition," College English (January, 1969), 267-320.

IIbid., 273. 
use the lab not only as a convenient place to use tape recorders, but also as a physical model for a course in writing where the movement would be from subjective to objective writing. The students would begin in relative isolation writing their own interior monologues primarily for self. We later called this the ego-id communication. They would progress through dramatic monologue, subjective narration, detached autobiography, observer narrator, biography, and anonymous narrator. As they moved from subjective to increasingly objective points of view, they would also have need for each other as audiences and would begin to communicate with the student in the next booth, sometimes invite them into theirs, and at other times express the need for the whole class as audience. Sometimes we would probably need to leave the lab and go to another room to share works with the entire class.

The courses that evolved were offered in the fall quarters of 1972 and 1973. The students who enrolled had no idea that they were going to be exposed to an experimental approach, but at the first class meeting the 25 enrollees were warned and given a chance to drop the course. Only one student did, in fact. The course met in the language lab, which is usually used for foreign language instruction. The lab is equipped with individual booths for students; each booth has a tape recorder, headset, and panel of controls which the students learned to use the first day. The course met three times a week, an hour at a time, and the class meetings were held in the lab, with those exceptions mentioned above.

During the course, each student was asked to compose at least twenty-four different pieces of writing. The text (Word, Self, Reality by James Miller) was used to help students get ideas for writing and to give them a general philosophy of writing. Of the twenty-four writings each student was asked to do during the ten weeks, he was to choose at least six of his best efforts and hand these in at designated intervals during the quarter. In this way, only the student's best work would be evaluated by the instructor. A student was free to hand in as much as he wanted to, and most handed in more than the required six-some as mary as fifteen or twenty. Most sessions were taken up by student work in the lab, whether it meant using the tape recorders in various ways to compose, or using the time to talk with other students, read, write, revise, develop ideas for compositions, or hold individual conferences with the instructor. In the beginning, I had visualized all students arriving in class and working for fifty minutes in their "cells" and ending up with a piece of writing, one which would either be scrapped or worked on later, perhaps that night at home. It didn't always turn out that way. 


\section{Lab as Model}

Very few, if any, students wrote exactly 24 compositions in the 24 class periods; most probably wrote only a few more than those they handed in, and some just the required six. This enabled them, however, to spend more time on those writings they cared most about, and they were able to focus on problems in their writings by extensive revision and re-writing in many cases.

The students were told at the beginning of the course that they were to use the tapes to compose each day in class, and on their own free time, if they wanted. The language lab was available most hours of the day and night. I also described a few possible methods students could use, including actual oral composition by talking into the tape recorder and then transcribing onto paper; compiling notes and then expanding on them by taking into the tape recorder; writing something first, then reading it and revising it through the use of the tape recorder. They were also told that using the tapes might result in their being able to think subjects through more clearly and in a more systematic maner and also in greater problem solving accuracy.

As the quarter went on, many students were finding it difficult to compose orally on a regular basis. The "shyness" of students in using the tape recorders and the difficulty many of them had in adjusting to it as a tool were more severe than had been expected. Some of these students ended up using the tapes mainly for revision and proofreading. In individual conferences at the end of the quarter, ten students said that their main use of the tape recorders was to proof. read and revise papers; five said they used the tapes mainly to revise work; five said they used the tape recorders regularly to actually compose their writing; one person said he used it mainly to organize his ideas. Six said they used it primarily for ego-id dialogue in exploring topics. Most of the students said they felt the tape recorders were a valuable tool in helping them improve their writing. Most agreed that the tape recorders should be kept as a tool to help students, even if only in prewriting, proofreading, and revising.

The use of the language laboratory in encouraging students to "talk" their writing can be a big help. Almost every student showed writing improvement in such areas as organization, clarity, style, specificity, vocabularly, spelling mechanics, content, choice, and de-velopment. The students became interested enough in the writings of others that they began to insist on sharing. One of the ways this was done was through two issues of a dittoed magazine called Cells, named ambiguously for life spaces and the jail cells which the language lab booths resembled all too much. Two issues of this magazine were prepared by the class, one near the middle of the course and one at the end. 
The language lab provided a writing workshop that helped integrate talk and writing and at the same time deal with the more explicit, audience-centered expository/rhetorical skills of the more traditional composition course. Development of personal voice as well as objectivity were accelerated by the lab, not only as an information storage and retrieval system, but also as a physical model of the private (subjective) beginning of the course in the isolation of the booths and ego-id communication to the public (objective) discourse that came in the movement to the larger audience of the class discussion and finally to the even more public discourse published in the two issues of the class magazine. Writing is not only a communication skill but a means of self awareness. What-is-written-about and "the writing process" must be connected. The language laboratory serves as an excellent medium for making that connection.

ABOUT THE A.UTHOR:

Dr. Davis is Professor of English at Ohio University, Athens, Ohio. 